\title{
Biochemical Studies on the Treatment of Primary Hyperoxaluria
}

\author{
DOROTHY A. GIBBS and R. W. E. WATTS \\ From The Medical Professorial Unit (Dunn Laboratory), St. Bartholomew's Hospital, London
}

The increased urinary oxalate excretion which is characteristic of primary hyperoxaluria causes recurrent urinary calculi and nephrocalcinosis, with death at an early age (Hall, Scowen, and Watts, 1960; Hockaday, Clayton, Frederick, and Smith, 1964), and no effective treatment for the disease has been reported. Glyoxylate is the main immediate metabolic precursor of oxalate, and if the enzyme or enzymes which catalyse the oxidation<smiles>O=CC(=O)C(C(=O)O)C(=O)O</smiles>

could be inhibited in vivo the urinary oxalate excretion should be reduced and renal damage averted. The enzymes which catalyse this oxidation of glyoxylate to oxalate in vivo have not been identified, but xanthine oxidase (xanthine oxygen: oxidoreductase (Enzyme Classification 1.2.3.2.)), aldehyde dehydrogenase (aldehyde: NAD oxidoreductase (E.C. 1.2.1.3.)), and aldehyde oxidase (aldehyde : oxygen oxidoreductase (E.C. 1.2.3.1.)) catalyse the oxidation of a wide range of aldehydes to carboxylic acids. Allopurinol (Gibbs and Watts, 1966), disulfiram (Graham, 1951), and acetomenaphthone (Rajagopalan, Fridovich and Handler, 1962) inhibit aldehyde oxidations by xanthine oxidase, aldehyde dehydrogenase, and aldehyde oxidase respectively in vitro.

Experimental pyridoxine deficiency produces calcium oxalate nephrocalcinosis and urinary calculi in the cat and rat (Gershoff, Faragalla, Nelson, and Andrus, 1959a; Andrus, Gershoff, and Faragalla, 1959). Faber, Feitler, Bleiler, Ohlson, and Hodges (1963) demonstrated hyperoxaluria in human subjects given pyridoxine-deficient diets, but hyperoxaluria was not observed in an infant with dietary

Received November 22, 1966. pyridoxine deficiency (Scriver and Hutchison, 1963). Gershoff, Mayer, and Kulczycki (1959b) reported that the urinary excretion of oxalate by normooxaluric human subjects in whom there was no reason to suspect dietary pyridoxine deficiency was reduced by giving pyridoxine, and that this effect was enhanced if folic acid was administered concurrently. Ludwig (1963) reported a patient with urinary stones and hyperoxaluria whose urinary oxalate excretion decreased when pyridoxine was given. Elder and Wyngaarden (1960) also studied a patient whose hyperoxaluria disappeared after she was admitted to hospital, and they have recently suggested that an unsuspected dietary deficiency may have been corrected in this case (Wyngaarden and Elder, 1966). Mayer, Al-Waidh, Karp, and Zinsser (1961) reported that most oxalate stone formers showed biochemical evidence of pyridoxine deficiency.

This paper reports a study of the effects of giving allopurinol, disulfiram, acetomenaphthone, pyridoxine, and pyridoxine with folic acid, on the urinary oxalate excretion in primary hyperoxaluria. The oxalate excretion was also studied at two levels of protein intake.

\section{Patients and Methods}

The patients were in hospital but ambulant during the studies.

Patient 1. She was an asymptomatic 7-year-old girl, height $119 \mathrm{~cm}$., weight $22 \cdot 8 \mathrm{~kg}$., with bilateral renal calculi, blood urea $62 \mathrm{mg} . / 100 \mathrm{ml}$., and grossly raised urinary oxalate excretion (Table I). Her clinical state remained unchanged during these studies. The parents are unrelated, and one sib has died from uraemia associated with renal calculi, systemic oxalate deposits (oxalosis) being demonstrated at necropsy. The patient's condition deteriorated about three months after the completion of the present studies, and she died from uraemia, widespread oxalosis being observed. During the present investigations she took a diet which provided 
TABLE I

Effects of Allopurinol, Disulfiram, and Acetomenaphthone on Urinary Oxalate Excretion in Primary Hyperoxaluria

\begin{tabular}{|c|c|c|c|c|c|c|c|c|}
\hline \multirow{2}{*}{\multicolumn{2}{|c|}{ Period }} & \multirow{3}{*}{ Drug Régime } & \multicolumn{6}{|c|}{ Oxalate Excretion } \\
\hline & & & \multicolumn{3}{|c|}{ (mg. $\left.(\mathrm{COOH})_{2} \cdot 2 \mathrm{H}_{2} \mathrm{O} / 24 \mathrm{hr}.\right)$} & \multicolumn{3}{|c|}{ (mg. $(\mathrm{COOH})_{2} \cdot 2 \mathrm{H}_{2} \mathrm{O} / \mathrm{mg}$. Creatinine) } \\
\hline 1vo. & (dy.) & & Range & Mean & $\begin{array}{c}\text { Standard } \\
\text { Deviation }\end{array}$ & Range & Mean & $\begin{array}{l}\text { Standard } \\
\text { Deviation }\end{array}$ \\
\hline \multicolumn{2}{|c|}{ Patient No. 1} & \multirow{11}{*}{ 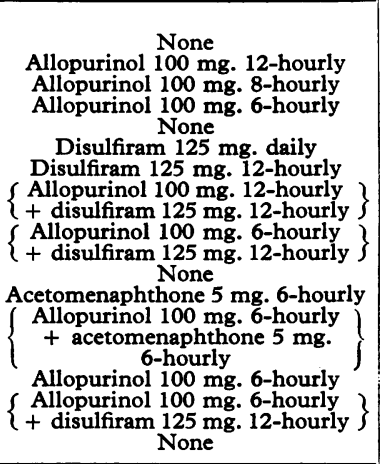 } & & & & & & \\
\hline $\begin{array}{l}1 \\
2 \\
3\end{array}$ & $\begin{array}{r}9 \\
11 \\
4\end{array}$ & & $\begin{array}{l}133-207 \\
136-178 \\
151-162\end{array}$ & $\begin{array}{l}172 \\
157 \\
-\end{array}$ & $\begin{array}{l}26 \\
13 \\
\end{array}$ & $\begin{array}{l}0 \cdot 215-0 \cdot 451 \\
0 \cdot 231-0 \cdot 298 \\
0 \cdot 255-0 \cdot 270\end{array}$ & $\begin{array}{l}0.302 \\
0.267 \\
-\end{array}$ & $\begin{array}{l}0.068 \\
0.023 \\
-\end{array}$ \\
\hline $\begin{array}{l}4 \\
5\end{array}$ & 16 & & $\begin{array}{l}121-217 \\
137-172\end{array}$ & $\begin{array}{l}159 \\
160\end{array}$ & $\begin{array}{l}25 \\
15\end{array}$ & $\begin{array}{l}0.209-0.388 \\
0.226-0.405\end{array}$ & $\begin{array}{l}0.284 \\
0.284\end{array}$ & $\begin{array}{l}0.052 \\
0.049\end{array}$ \\
\hline $\begin{array}{l}6 \\
7\end{array}$ & $\begin{array}{r}3 \\
21\end{array}$ & & $\begin{array}{l}151-158 \\
137-168\end{array}$ & $\overline{151}$ & $\frac{7}{10}$ & $\begin{array}{l}0 \cdot 232-0 \cdot 266 \\
0 \cdot 200-0 \cdot 345\end{array}$ & $0 . \overline{253}$ & $0 . \overline{035}$ \\
\hline 8 & 5 & & $138-187$ & 154 & 21 & $0 \cdot 209-0 \cdot 302$ & $0 \cdot 247$ & 0.035 \\
\hline 9 & 11 & & $115-155$ & 138 & 17 & $0 \cdot 198-0 \cdot 272$ & $0 \cdot 235$ & $0 \cdot 027$ \\
\hline $\begin{array}{l}10 \\
11\end{array}$ & $\begin{array}{l}21 \\
13\end{array}$ & & $\begin{array}{l}114-229 \\
182-224\end{array}$ & $\begin{array}{l}168 \\
197\end{array}$ & $\begin{array}{l}28 \\
13\end{array}$ & $\begin{array}{l}0 \cdot 147-0 \cdot 389 \\
0 \cdot 225-0 \cdot 356\end{array}$ & $\begin{array}{l}0 \cdot 263 \\
0 \cdot 283\end{array}$ & $\begin{array}{l}0.063 \\
0.032\end{array}$ \\
\hline 12 & 10 & & $199-214$ & 204 & 6 & $0 \cdot 260-0 \cdot 318$ & $0 \cdot 283$ & 0.024 \\
\hline 13 & 9 & & $156-211$ & 189 & 15 & $0 \cdot 239-0 \cdot 346$ & $0 \cdot 286$ & 0.038 \\
\hline 14 & 47 & & $114-221$ & 173 & 27 & $0 \cdot 143-0 \cdot 396$ & $0 \cdot 254$ & 0.050 \\
\hline 15 & 10 & & $155-206$ & 175 & 14 & $0 \cdot 284-0 \cdot 445$ & 0.357 & 0.046 \\
\hline $\begin{array}{c}\text { Patient } \\
1 \\
2 \\
3\end{array}$ & $\begin{array}{r}0.2 \\
12 \\
16 \\
12\end{array}$ & $\begin{array}{l}\text { None } \\
\text { Allopurinol } 100 \mathrm{mg} .6 \text {-hourly } \\
\text { None }\end{array}$ & $\begin{array}{l}162-319 \\
171-276 \\
129-379\end{array}$ & $\begin{array}{l}232 \\
225 \\
263\end{array}$ & $\begin{array}{l}40 \\
27 \\
69\end{array}$ & $\begin{array}{l}0 \cdot 264-0 \cdot 400 \\
0 \cdot 280-0 \cdot 506 \\
0 \cdot 303-0 \cdot 439\end{array}$ & $\begin{array}{l}0 \cdot 339 \\
0 \cdot 377 \\
0 \cdot 359\end{array}$ & $\begin{array}{l}0 \cdot 040 \\
0 \cdot 073 \\
0 \cdot 038\end{array}$ \\
\hline
\end{tabular}

a calculated intake of $155 \mathrm{~g}$. carbohydrate, $50 \mathrm{~g}$. protein, $65 \mathrm{~g}$. fat, $22 \mathrm{mg}$. ascorbic acid, and 1400 calories $/ 24 \mathrm{hr}$. Foods which are especially rich in oxalate and ascorbic acid (rhubarb, strawberries, beets, spinach, chocolate, tea, cocoa, and citrus fruits) were excluded from the diet.

Patient 2. He was an asymptomatic 12-year-old boy, height $133 \mathrm{~cm}$., weight $30.7 \mathrm{~kg}$., with a right renal calculus, blood urea $40 \mathrm{mg} . / 100 \mathrm{ml}$., and grossly raised urinary oxalate excretion. (He was reported as 'Case 4' in 'Family 4' of Hall et al. (1960).) His diet was unrestricted except that the high oxalate foods and citrus fruits were excluded.

Patient 3. She was an asymptomatic 14-year-old girl, height $183 \mathrm{~cm}$., weight $46.5 \mathrm{~kg}$., referred to as 'Subject 3' in a previous study (Crawhall and Watts, 1962). She had bilateral renal calculi, blood urea $34 \mathrm{mg}$. $/ 100 \mathrm{ml}$., and grossly increased urinary oxalate excretion.

Urine collections. The urine was filtered quickly

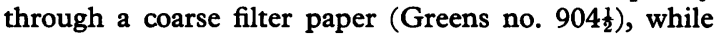
still warm, the filtrate being collected in a bottle containing conc. $\mathrm{HCl}(50 \% \mathrm{w} / \mathrm{v})$; any calculi present were removed from the filter, and the paper was washed with approximately $10 \mathrm{ml}$. N.HC1, the washings being added to the main bulk of the filtrate.

Analytical methods. The methods used were: (a) for oxalate-isotope dilution analysis-Dean and Griffin (1965), except that Bray's (1960) scintillator solution was used); (b) for urinary uric acid-Liddle, Seegmiller, and Laster (1959); (c) for urinary oxypurines
-Goldfinger, Klinenburg, and Seegmiller (1965), as modified by Watts, Watkins, Matthias, and Gibbs (1966); (d) for urinary creatinine-Peters and Van Slyke (1932).

\section{Results}

The urinary oxalate excretion by Patient 1 was unaltered by giving allopurinol, disulfiram, or acetomenaphthone either singly or in the following combinations-allopurinol with disulfiram, and allopurinol with acetomenaphthone (Table I). During the control periods this patient's urinary uric acid was $200-350 \mathrm{mg}$. $/ 24 \mathrm{hr}$. with a negligible excretion of oxypurines, whereas when allopurinol was given the urinary uric acid level was $75-150 \mathrm{mg}$./ $24 \mathrm{hr}$., the oxypurine excretion being 70-125 mg./ $24 \mathrm{hr}$. (calculated as xanthine). These results show that xanthine oxidase was being inhibited by the drug. Allopurinol also failed to influence the urinary oxalate excretion in the study on Patient 2 (Table I), and in an adult patient (Gibbs and Watts, 1967) who was given the drug for 4 months (mean urinary oxalate excretion before and during the treatment being $132 \mathrm{mg} . / 24 \mathrm{hr}$. (range 102-168; standard deviation 20 ; 10 observations) and $135 \mathrm{mg} . / 24 \mathrm{hr}$. (range 81-258; standard deviation $33 ; 29$ observations), respectively (calculated as $\left.(\mathrm{COOH})_{2} .2 \mathrm{H}_{2} \mathrm{O}\right)$.

The urinary oxalate excretion by Patient 3 was 
TABLE II

Effect of Protein Restriction, Pyridoxine, and Pyridoxine Plus Folic Acid Administration on Urinary Oxalate Excretion in Primary Hyperoxaluria

\begin{tabular}{|c|c|c|c|c|c|c|c|c|}
\hline \multicolumn{2}{|c|}{ Period } & \multirow{3}{*}{ Drug Régime } & \multicolumn{6}{|c|}{ Oxalate Excretion } \\
\hline $\mathrm{Na}$ & Duntion & & \multicolumn{3}{|c|}{ (mg. $(\mathrm{COOH})_{2} \cdot 2 \mathrm{H}_{2} \mathrm{O} / 24 \mathrm{hr}$.) } & \multicolumn{3}{|c|}{ mg. $(\mathrm{COOH})_{2} \cdot 2 \mathrm{H}_{2} \mathrm{O} / \mathrm{mg}$. Creatinine) } \\
\hline No. & $\begin{array}{c}\text { Duration } \\
(\text { dy.) }\end{array}$ & & Range & Mean & $\begin{array}{l}\text { Standard } \\
\text { Deviation }\end{array}$ & Range & Mean & $\begin{array}{c}\text { Standard } \\
\text { Deviation }\end{array}$ \\
\hline 1 & 7 & $\begin{array}{l}\text { Diet unrestricted except for } \\
\text { omission of high oxalate } \\
\text { foods, etc. (see text) }\end{array}$ & $172-223$ & 199 & 21 & $0 \cdot 153-0 \cdot 199$ & $0 \cdot 175$ & 0.017 \\
\hline $\begin{array}{l}2 \\
3 \\
4\end{array}$ & $\begin{array}{r}9 \\
14 \\
17\end{array}$ & $\begin{array}{l}\star 70 \text { g. protein diet } \\
+35 \text { g. protein diet } \\
35 \text { g. protein diet plus } \\
\text { pyridoxine HCl } 250 \mathrm{mg} .\end{array}$ & $\begin{array}{l}210-254 \\
175-245 \\
187-234\end{array}$ & $\begin{array}{l}234 \\
211 \\
209\end{array}$ & $\begin{array}{l}13 \\
65 \\
13\end{array}$ & $\begin{array}{l}0 \cdot 195-0 \cdot 220 \\
0 \cdot 148-0 \cdot 213 \\
0 \cdot 158-0 \cdot 200\end{array}$ & $\begin{array}{l}0 \cdot 206 \\
0 \cdot 184 \\
0 \cdot 181\end{array}$ & $\begin{array}{l}0.009 \\
0.020 \\
0.012\end{array}$ \\
\hline 5 & 10 & $\begin{array}{l}35 \text { g. protein diet plus } \\
\text { pyridoxine HC1 } 250 \mathrm{mg} \text {. } \\
\text { 6-hourly and folic acid } 5 \mathrm{mg} \text {. } \\
\text { 6-hourly }\end{array}$ & $228-251$ & 242 & 8 & $0 \cdot 181-0 \cdot 218$ & $0 \cdot 204$ & 0.012 \\
\hline
\end{tabular}

* This diet provided a calculated $70 \mathrm{~g}$. protein, $370 \mathrm{~g}$. carbohydrate, $80 \mathrm{~g}$. fat, $35 \mathrm{mg}$. ascorbic acid, and $2400 \mathrm{cal} . / 24 \mathrm{hr}$.

† This diet provided a calculated $35 \mathrm{~g}$. protein, $400 \mathrm{~g}$. carbohydrate, $75 \mathrm{~g}$. fat, $30 \mathrm{mg}$. ascorbic acid, and $2300 \mathrm{cal} . / 24 \mathrm{hr}$.

The high oxalate foods and citrus fruits were both excluded from these diets (see text).

unaltered by large doses of pyridoxine, or by a combination of pyridoxine and folic acid (Table II). It was also shown that doubling this patient's protein intake did not affect her urinary oxalate excretion (Table II).

\section{Discussion}

The urinary oxalate excretion increases to adult levels by the age of approximately 12 years (unpublished data from this laboratory), and the present patients all had the grossly increased urinary oxalate excretion characteristic of primary hyperoxaluria. It is unlikely that a therapeutically useful diminution in the urinary oxalate excretion would have been obscured by rapid solution of calcium oxalate urinary calculi during these studies. Thus, in the analogous situation which arises when cystinuric patients are treated with penicillamine, the decrease in the urinary excretion is easily demonstrable when cystine stones are present (Crawhall, Scowen, and Watts, 1963, 1964). It is also of interest that the calcium oxalate is less soluble in urine (about $150 \mathrm{mg}$./litre at $p \mathrm{H} 6 \cdot 0$, calculated from the data of Miller, Vermeulen, and Moore (1958)), than cystine (about $300 \mathrm{mg}$./litre at the same $p H$ value, Dent and Senior (1955)).

The failure of the xanthine oxidase inhibitor allopurinol to reduce the urinary oxalate excretion in primary hyperoxaluria, even though an effective degree of enzyme inhibition was achieved as judged by the results of the uric acid and oxypurine determinations, agrees with our findings in non-hyperoxaluric subjects (Gibbs and Watts, 1966), and indicates that the role of this enzyme in oxalate production is not increased in the disease. Recent studies with hyperoxaluric patients' liver tissue (Gibbs and Watts, 1967) also showed that neither the over-all catalytic activity of the tissue, nor the extent to which this was mediated by xanthine oxidase, was increased in the disease. Similarly, the present negative results with disulfiram and acetomenaphthone suggest that aldehyde dehydrogenase and aldehyde oxidase, respectively, are either not responsible for the oxidation of glyoxylate to oxalate in vivo in primary hyperoxaluria, or that their inhibition can be compensated by increased activity of other enzyme systems.

Pyridoxine either alone or in combination with folic acid did not reduce the urinary excretion of oxalate in the present work. Hockaday et al. (1964) also mention that pyridoxine has been ineffective in the treatment of primary hyperoxaluria, though they give no details of the data on which this statement is based. The discrepancy between these results and those of Gershoff et al. (1959b) would be explicable if the metabolic pathway, the activity of which was altered by pyridoxine administration, contributes the same absolute amount of oxalate to the total urinary oxalate in primary hyperoxaluria as in normal subjects, this being small by comparison with the total urinary oxalate excretion in primary hyperoxaluria, but forming a large part of a normal subject's urinary oxalate excretion. In these circumstances fluctuations in response to pyridoxine administration, though apparent in normal subjects, might be no greater than the spontaneous fluctuations in the urinary oxalate excretion which occur in primary hyperoxaluria.

McLaurin, Beisel, McCormick, Scalettar, and Herman (1961) report that two patients with primary hyperoxaluria had no symptoms of urinary stones after being given pyridoxine though they both continued to have grossly raised urinary oxalate 
levels. The rate at which urinary stones form in patients with primary hyperoxaluria is variable, and there seems no reason to regard the outcome in these cases as having been altered by pyridoxine administration. Ludwig's (1963) patient had a lower oxalate excretion than is usually encountered in the disease except when there is severe renal failure, and it is possible that her hyperoxaluria was due to a different metabolic lesion from that which was present in the patients studied here; it is also possible that some of the changes which he observed could have been due to spontaneous fluctuations in the urinary oxalate excretion.

It is concluded that the recent observations suggesting a relation between pyridoxine intake and the level of urinary oxalate excretion have no therapeutic application in the treatment of primary hyperoxaluria.

\section{Summary}

The possibility of reducing the urinary oxalate excretion in primary hyperoxaluria by giving drugs that inhibit some of the enzymes which are known to oxidize aldehydes to carboxylic acids, has been investigated. Allopurinol (a xanthine oxidase inhibitor), disulfiram (an aldehyde dehydrogenase inhibitor), and acetomenaphthone (an aldehyde oxidase inhibitor) did not alter the urinary oxalate excretion. Allopurinol and disulfiram, given together, and allopurinol, with acetomenaphthone, were also ineffective. Thus, these enzymes do not appear to be specifically concerned with oxalate production in primary hyperoxaluria.

Pyridoxine and pyridoxine plus folic acid, which have been previously reported to reduce the urinary oxalate excretion did not lower the urinary oxalate excretion in the present studies.

The urinary oxalate excretion was unaltered by restricting the protein intake.

It is concluded that none of these measures has any place in the treatment of patients with primary hyperoxaluria.

We are pleased to acknowledge our indebtedness to Professor E. F. Scowen for his continued interest in this work, and to the Governors of St. Bartholomew's Hospital for their generous research grants. Dr. E. G. Hall arranged the study on Patient 2 at the Alder Hey Children's Hospital, Liverpool, and shipped the specimens to us for analysis. Dr. O. Wrong, Dr. N. R. Butler, and Dr. A. E. Dormer referred patients to R.W.E.W., and we greatly appreciate their continued interest in these investigations. We are also indebted to Mr. L. A. Rawlings, as well as to Sister J. Parke and the dieticians attached to the Metabolic Ward for their help in these investigations.

\section{REFERENCES}

Andrus, S. B., Gershoff, S. N., and Faragalla, F. F. (1959) Calcium oxalate renal calculi induced in rats by vitamin $\mathbf{B}_{6}$ deficiency. (Abstr.). Amer. F. Path., 35, 671.
Bray, G. A. (1960). A simple efficient liquid scintillator for counting aqueous solutions in a liquid scintillation counter. Analyt. Biochem., 1, 279.

Crawhall, J. C., Scowen, E. F., and Watts, R. W. E. (1963). Effect of penicillamine on cystinuria. Brit. med. f., 1, 588.

, - and - (1964). Further observations on use of D-penicillamine in cystinuria. ibid., 1, 1411.

- and Watts, R. W. E. (1962). The metabolism of $[1-14 \mathrm{C}]$ glyoxylate by the liver mitochondria of patients with primary hyperoxaluria and non-hyperoxaluric subjects. Clin. Sci., 23, 163.

Dean, B. M., and Griffin, W. J. (1965). Estimation of urinary oxalate by the method of isotope dilution. Nature (Lond.), 205, 598.

Dent, C. E., and Senior, B. (1955). Studies on the treatment of cystinuria. Brit. F. Urol., 27, 317.

Elder, T. D., and Wyngaarden, J. B. (1960). The biosynthesis and turnover of oxalate in normal and hyperoxaluric subjects. 7. clin. Invest., 39, 1337.

Faber, S. R., Feitler, W. W., Bleiler, R. E., Ohlson, M. A., and Hodges, R. E. (1963). The effects of an induced pyridoxine and pantothenic acid deficiency on excretions of oxalic and xanthurenic acids in the urine. Amer. F. clin. Nutr., 12, 406.

Gershoff, S. N., Faragalla, F. F., Nelson, D. A., and Andrus, S. B. (1959a). Vitamin $B_{6}$ deficiency and oxalate nephrocalcinosis in the cat. Amer. F. Med., 27, 72.

_, Mayer, A. L., and Kulczycki, L. L. (1959b). Effect of pyridoxine administration on the urinary excretion of oxalic acid, pyridoxine, and related compounds in mongoloids and nonmongoloids. Amer. F. clin. Nutr., 7, 76.

Gibbs, D. A., and Watts, R. W. E. (1966). An investigation of the possible role of xanthine oxidase in the oxidation of glyoxylate to oxalate. Clin. Sci., 31, 285.

- and - (1967). Oxalate formation from glyoxylate in primary hyperoxaluria: Studies on liver tissue. ibid., 32, 351.

Goldfinger, S., Klinenberg, J. R., and Seegmiller, J. E. (1965). The renal excretion of oxypurines. f. clin. Invest., 44, 623.

Graham, W. D. (1951). In vitro inhibition of liver aldehyde dehydrogenase by tetraethylthiuram disulfide. $\mathcal{F}$. Pharm. Pharmacol., 3, 160.

Hall, E. G., Scowen, E. F., and Watts, R. W. E. (1960). Clinical manifestations of primary hyperoxaluria. Arch. Dis. Childh., 35, 108.

Hockaday, T. D. R., Clayton, J. E., Frederick, E. W., and Smith, L. H., Jr. (1964). Primary hyperoxaluria. Medicine (Baltimore), 43, 315.

Liddle, L., Seegmiller, J. E., and Laster, L. (1959). The enzymatic spectrophotometric method for determination of uric acid. 7. Lab. clin. Med., 54, 903.

Ludwig, G. D. (1963). Renal calculi associated with hyperoxaluria. Ann. N.Y. Acad. Sci., 104, 621.

McLaurin, A. W., Beisel, W. R., McCormick, G. J., Scalettar, R., and Herman, R. H. (1961). Primary hyperoxaluria. Ann. intern. Med., 55, 70.

Mayer, G. M., Al-Waidh, M. N., Karp, F., and Zinsser, H. H. (1961). Effect of intramuscular vitamin $\mathbf{B}_{6}$ administration in stone-forming patients. Division of Biological Chemistry of the American Chemical Society. Chicago. Abstract No. 164. p. 67C.

Miller, G. H., Vermeulen, C. W., and Moore, J. D. (1958). Calcium oxalate solubility in urine: experimental urolithiasis XIV. F. Urol. (Baltimore), 79, 607.

Peters, J. P., and Van Slyke, D. D. (1932). Quantitative Clinical Chemistry, Vol. 2, p. 602. Williams and Wilkins, Baltimore.

Rajagopalan, K. V., Fridovich, I., and Handler, P. (1962). Hepatic aldehyde oxidase. I. Purification and properties. $\mathcal{F}$. biol. Chem., 237, 922.

Scriver, C. R., and Hutchison, J. H. (1963). The vitamin B $_{6}$ deficiency syndrome in human infancy: biochemical and clinical observations. Pediatrics, 31, 240.

Watts, R. W. E., Watkins, P. J., Matthias, J. Q., and Gibbs, D. A. (1966). Allopurinol and acute uric acid nephropathy. Brit. med. F., 1, 205.

Wyngaarden, J. B., and Elder, T. D. (1966). Primary hyperoxaluria and oxalosis. In The Metabolic Basis of Inherited Disease, 2nd edn., ed. J. B. Stanbury, J. B. Wyngaarden, and D. S. Fredrickson, p. 189. McGraw-Hill, New York. 